\title{
BUILDING 21-CENTURY INDONESIAN TEACHERS' TEACHING CAPACITIES THROUGH THE INTEGRATION OF TECHNOLOGY INTO CLASSROOMS*
}

\author{
Daniel Ginting ${ }^{1}$ \\ ${ }^{1}$ Universitas Ma Chung, daniel.ginting@machung.ac.id
}

\begin{abstract}
This research aimed to present an empirical sketch on the implementation of the IMOOC (Indonesian Massive Open Online Course). This online program sought to raise teachers' awareness of the importance of technology for teaching while at the same time promoting their teaching skills in using technology for learning. The samples of this study included thirty-seven pre and in-service English teachers. This study found the IMOOC served as a reliable online instruction promoting essential aspects of 21-century education such as critical thinking, collaborative, creative and innovative learning, self-reliance, and individualized learning.
\end{abstract}

Key Terms: MOOC, critical thinking, collaborative, creative and innovative learning, autonomy, and individualized learning

\section{INTRODUCTION}

The rapid advancement of communication and information technology today has transformed a social life of the societies worldwide. This technology makes world communities globalized and inevitably have encouraged education reformers to embrace the $21^{\text {st }}$ century skills in order to make a steady progress in todays' technology-saturated world (Smith, 1990; Jerald, 2009). Nevertheless, not a few teachers nowadays are still preoccupied with traditional practices. Giving students limited opportunities of collaborative work, focusing on enforcement of official rules and proper behavior, conducting teacher-centered where the teacher was commonly located at the front or center of the room, having limited use of technology into classrooms are common practices in such traditional teaching contexts (Fox \& McDermott, 2015; Pink, 2005). 21st-century education gives a new challenge for education practitioners worldwide to reflect upon their current educational practices.

Numerous writers have extensively discussed $21^{\text {st }}$ century education (Pink, 2005; Shear, Novais, Means, Gallager \& Langworthy, 2010; Crockett, Jukes, \& Churches, 2011, Ravitz, Hixson, English \& Mergendoller, 2012, Little, 2013, Fox \& McDermott, 2015). 21st-

* DOI: 10.33479/klausa.v2i02.154 
century education should be promoting students' competence to critically think, analyze, investigate, and innovate in a competitive world (Pink, 2005). This competence becomes the necessity since digital content is developing in numbers and complexness, real-life, and realtime tasks (Crockett, Jukes, \& Churches, 2011). Models of teaching and learning should be emphasized on self-regulation assessments, collaborative work, knowledge-building, and project-based activities

(Shear, Novais, Means, Gallager \& Langworthy, 2010). It also promotes education for sustainable development (Bell, 2016): moving from being teacher-centered to being studentcentered. This should be accompanied with greater emphasis on integrating technology into education (Ravitz, Hixson, English \& Mergendoller, 2012; Little, 2013; Fox \& McDermott, 2015).

This paper aims to present a descriptive sketch upon $21^{\text {st }}$-century education practices using an online-based instruction, the Indonesian Massive Open Online Course (shortened to IMOOC). While the current literature shows research topics on building 21-century teachers' competence has not been extensively discussed, this paper aims to fill in the gap to enrich the understanding and extend the horizon about the implementation of 21-century education.

\section{RESEARCH METHOD}

The IMOOC was Indonesian-made MOOC developed by Indonesian English instructors and devoted to Indonesian teachers teaching English. Having been funded by the Department of State and launched at @america in February 2017, the IMOOC program was carried out from mid-February to mid-April 2017 in fifteen cities in Indonesia. This online instruction model was intended to build Indonesian teachers' autonomous learning attitude in mastering the use technology for teaching and learning in language classrooms. This online program had five modules: Autonomous Learning (Module One), Digital Literacy (Module Two), Mobile Devices for Autonomous Teaching and Learning (Module Three), Autonomous Learning Using Videos (Module Four), and Autonomy for Video Creation (Module Five). The teaching instructions and tasks in the IMOOC are summarized in Table 1.

\begin{tabular}{|c|c|c|c|c|c|c|c|}
\hline \multirow{2}{*}{ MODULE } & \multicolumn{2}{|c|}{$\begin{array}{c}\text { TEACHING } \\
\text { INSTRUCTIONS }\end{array}$} & \multicolumn{4}{|c|}{ TASKING } & \multirow{2}{*}{$\begin{array}{c}\text { TOTAL } \\
\text { ACTIVITIES }\end{array}$} \\
\hline & READING & MOVIES & $\begin{array}{l}\text { MULTIPLE } \\
\text { CHOICE }\end{array}$ & DISCUSSION & $\begin{array}{c}\text { PEER } \\
\text { REVIEWS }\end{array}$ & PROJECTS & \\
\hline One & 4 & 0 & 1 & 5 & 1 & 2 & $\begin{array}{c}13 \\
(18 \%)\end{array}$ \\
\hline Two & 6 & 2 & 2 & 4 & 1 & 2 & $\begin{array}{c}17 \\
(24 \%)\end{array}$ \\
\hline Three & 6 & 5 & 1 & 3 & 1 & 2 & $\begin{array}{c}18 \\
(25 \%)\end{array}$ \\
\hline Four & 5 & 4 & 0 & 2 & 1 & 1 & $\begin{array}{c}13 \\
(18 \%)\end{array}$ \\
\hline Five & 4 & 1 & 0 & 0 & 2 & 3 & $\begin{array}{c}10 \\
(14 \%)\end{array}$ \\
\hline
\end{tabular}




\begin{tabular}{|l|c|c|c|c|c|c|c|}
\hline Total & $25(35 \%)$ & $\begin{array}{c}12 \\
(17 \%)\end{array}$ & $\begin{array}{c}4 \\
(6 \%)\end{array}$ & $\begin{array}{c}14 \\
(20 \%)\end{array}$ & $\begin{array}{c}6 \\
(8 \%)\end{array}$ & $\begin{array}{c}10 \\
(14 \%)\end{array}$ & $\begin{array}{c}71 \\
(100 \%)\end{array}$ \\
\hline
\end{tabular}

Table 1. Teaching Instructions and Tasking in the IMOOC

This study involved about thirty-seven pre- and in-service teachers as the research samples after they had undergone selection process. The selection of the IMOOC participants started in January 2017. About one hundred fifty participants across East Province underwent the selection process: writing a 1000-word-essay depicting "the Integration of Technology into Classrooms." Two primary aspects became the scoring priority in assessing the essays: the content and language. Upon the completion of the test, thirty-seven out of one hundred fifty people were considered eligible to attend the IMOOC from February 20, 2017, to May 29, 2017. Some essential information in the IMOOC such as discussion threads, peer-review, and projects became the primary data which were later analyzed through content analysis.

\section{FINDINGS AND DISCUSSION}

\section{Critical Thinking}

The discussion was one of the tasks in the IMOOC whose purpose was to provide the participants with learning opportunities to investigate different ideas and put course material into real life (Arend, 2009). They were challenged to share their reflective thinking, focusing on what to believe or do (Norris \& Ennis, 1989). To encourage all participants to think critically, the participants were required to read texts, watch movies before responding to the prompts (questions) in the discussion thread. The participants were also told to support their ideas based on credible sources. In most discussions, the participants tended to follow the following pattern: the triggering event, exploration, integration, and resolution (Garrison, Anderson, \& Archer, 2001).

First, the triggering event is a phase that induces the learners to solve the problems using their critical thinking (Rodgers, 2002). The prompts (questions) posted in the beginning part of discussions served as stimuli. These questions lead the learners to a sense of puzzlement (Redmond, 2014). The followings are the examples of question the participants had to respond in the IMOOC: How are teaching and learning using mobile apps (WhatApp, Quizlet, and Socrative) different from that of the traditional model? Do you agree that the mobile devices can promote favorable autonomous learning? If so, in what ways? As far as your experience is concerned, do you think that mobile devices can also hamper learning?

In the exploration phase, the participants exchanged information or shared alternative perspectives with each other (Redmond, 2014; Garrison \& Anderson, 2003). Delayed responses were common to notice during the exploration phase. The participants usually needed time to process information and think about the issues (Arend, 2009). As they began exchanging ideas, they sometimes disagreed with one another about the credibility of the sources, logics, and content of the arguments.

During the integration phase, the participants connected information collected in the previous exploration phase (Redmond, 2014). The integration occurred when the participants 
began to connect other ideas with their own. This study found they usually initiated their posting by addressing other participants' names in the integration stage. Addressing other participants' names may imply the intention to build their social bonds (pathic) in the online learning.

In the last stage, resolution, the participants identified or found solutions to their problems. They sometimes defended their beliefs if the new solutions could be applied to their educational contexts or workplace settings (Garrison \& Arbaugh, 2007) or through experiments (Garrison, Anderson, \& Archer, 2001).

\section{Collaboration (Cooperative Learning)}

Promoting a collaborative work through peer review was one of the teaching deliveries in the IMOOC. Before submitting their individual projects such as lesson plans, movies, infographics, all participants were assigned to evaluate their friends work based on new information and knowledge they had learned. In so doing, the participants got involved in situations build interactively a joint solution to some problems (Dillenbourg \& Schneider, 1995). Interactions among the participants made positive contributions to their learning (Laurillard, 1993; Moore, 1993; Ramsden, 1992). Cognitive enrichment was mediated by verbal exchanges among the participants during the review process and thus enhanced their learning capacities (Pressley \& McCormick, 1995).Giving feedback in online learning enables the participants to share their critical views on other peers' work (Guardado \& Shi, 2007).

Curtis \& Lawson mentioned the importance of a blended learning, that is, planned activities between face-to-face meeting and asynchronous online interactions (Curtis \& Lawson, 2001).This became the necessity due to communication limitations imposed by the lack of good real-time interaction support tools in online learning. Guardado \& Shi (2007) also noticed another problem with online learning: certain students did not have confidence to share their ideas during peer commenting activities. They preferred to withdraw from activities, which made online peer feedback one-way communication process. This unfavorable condition resulted in a high percentage of peer comment negligence (Guardado \& Shi, 2007)

To combat these problems, online instructors could use jigsaw method. In this method, teachers assigned individuals with tasks and roles in advance. In so doing, the timeconsuming element would be less evident. Conducting face-to-face discussions with teachers in the classrooms was one of the best strategies to exploit the effects of online peer feedback (Curtis \& Lawson, 2001; Guardado \& Shi, 2007).

\section{Individualizing Instructions}

Individualizing instruction is one of the instructional teaching deliveries in the IMOOC. This method has been effective strategies for meeting the needs of at-risk students (Archambault, Diamond, Brown, Cavanaugh, Coffey, Foures-Aalbu., \& Zygouris-Coe, 2010). This approach starts with the needs of the one student who has learning difficulties. Their learning difficulties were reflected in their poor performance in several assessments such as discussion, peer review, multiple choice, and projects. Above all, they usually could 
not complete the tasks properly, especially when it came to submitting their projects such as developing lesson plans, designing infographics, creating movies, and so on. These tasks were the most challenging since they demanded higher order of thinking.

\section{Figure 1. Infographic Project "How to be a Digitally Literate English Teachers" in the IMOOC}

\section{How to be a Digitally Literate English Language Teacher}

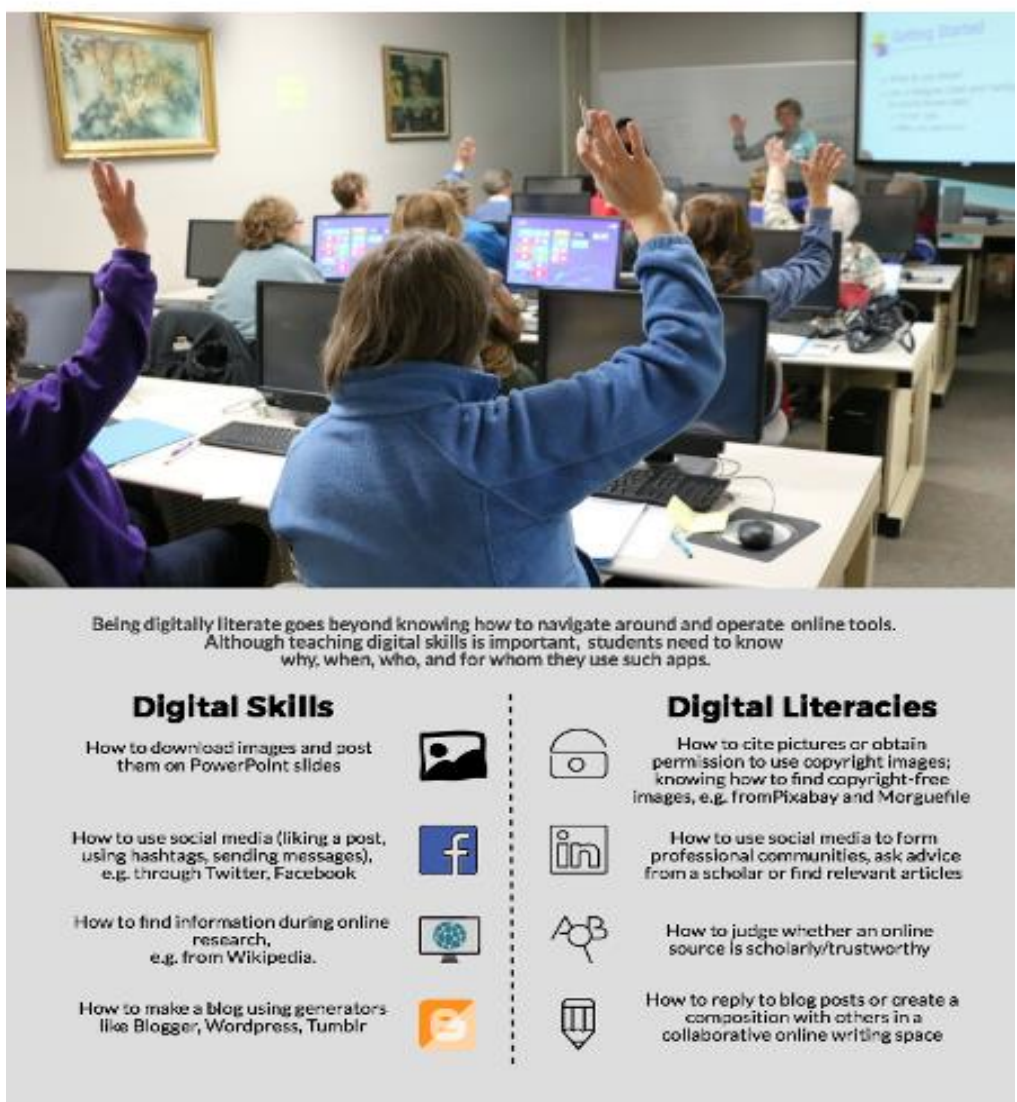

Providing low achievers with extra time was not always easy to do. In addition to willingly prepare special time, the instructor was also required to be flexible to deal with low achievers. However, research findings have shown giving extra time to guide them was an effective way to help them catch up the modules (Slavin, 1987). During the IMOOC, the instructor had used several ways to help low achievers with the guidance either through asynchronous (emails, Google doc) or synchronous media (Whatsapp). Face to face meeting was also helpful for them who lived in the same city with the instructor to catch up the lessons. The IMOOC as an online course extended a lot of opportunities for students who needed to amplify learning time to successfully deal with difficult concepts, an approach that was successful at creating innovative classroom-based and online schools (Cavanaugh, 2009; Twigg, 2003). 


\section{Creativity and Innovation}

Creativity and innovation were behavioral models the IMOOC concerned. This program encouraged the participants to take responsibility for their own learning. Being allowed to choose empowered them to discover the intimate bond between real freedom, selfresponsibility, and creativity (Kaufman, 2013). During the implementation of the IMOOC, creativity and innovation became apparent as they collaborated with others, and had access to peers who shared expertise in the particular technology (Barber, King, \& Buchanan, 2015). Teacher-learner-teacher role shifts and extended relationship were among the examples of creativity and innovation.

During the course, the roles in this online learning community became almost indecipherable. It was common to see that instructor and participants shift the roles. The students with expertise in particular technologies took on the role of instructor, the teacher became the learner, thus empowering learners with the confidence to take risks, make mistakes, and ask for help.

The relationship of brotherhood among IMOOC participants was growing stronger along with the length of time they studied in this online learning. Even after the IMOOC program was completed, they were still in communication through social media like Whatsapp. They shared experiences of learning, knowledge and skills of using new technologies for learning. This communication pattern among IMOOC participants has proved that learning did not always take place in formal institutions. Learning is a social endeavor.

\section{Self-Direction and Independence}

The IMOOC demanded the participants to be self-directed learners in the sense that they had to take responsibilities for their own learning (Garrison, 1997; 2003). The lack of synchronous interaction with the structure to get instant feedback from the instructor challenged them to solve their own problems themselves. They had to construct the meanings of the reading texts. They had to put their new understanding into practice through discussion with their peers. In addition, they were also required to prepare their projects and discussed them through peer review activities.

To promote self-directed and independent IMOOC participants, some strategies had been employed. First, the instructor provided guidance about technical issues at the IMOOC modules such as how to upload videos in Youtube; how to submit the project; how to do peer review; how to prepare portfolios). The participants could refer to this guidance anytime they have technical difficulties. Second, scheduling all tasks with due dates was another strategy to help the participants become independent learners. With this well-structured instruction, the participants were able to manage their time and complete their assignments in time. Third, creating a Whatssapp group of the participants was also very effective to do during the implementation of the IMOOC. A lot of participants admitted this social media was very helpful to remind them about the assignment due, to clarify the procedure of projects, and to motivate them to complete the tasks. This social media made them connected one to another. 


\section{CONCLUSION}

Educational personnel should reform education practice in facing the digital era. 21stcentury education requires teachers to promote ways to educate students that lead to the formation of critical thinking, collaborative, creative and innovative learning, self-reliance, and individualized learning. Besides supported by technology, the success of learning also needs to be supported by cooperation between strong willingness of participants to learn and creativity of instructors in creating a conducive online learning community.

\section{ACKNOWLEDGEMENTS}

The author would like to extend his gratitude to RELO and the Department of State for their encouragement and financial supports so that both the development and implementation of the IMOOC becomes possible. The author also thanks Humboldt conference committees for allowing this paper to be presented at the seminar in Jakarta on 24-26 July 2017.

\section{REFERENCES}

Archambault, L., Diamond, D., Brown, R., Cavanaugh, C., Coffey, M., Foures-Aalbu, D., \& Zygouris-Coe, V. (2010). Research Committee Issues Brief: An Exploration of AtRisk Learners and Online Education. International Association for K-12 Online Learning.

Arend, B. (2009). Encouraging critical thinking in online threaded discussions. Journal of Educators Online, 6(1), n1.

Barber, W., King, S., \& Buchanan, S. (2015). Problem Based Learning and Authentic Assessment in Digital Pedagogy: Embracing the Role of Collaborative Communities. Electronic Journal of e-Learning, 13(2), 59-67.

Bell, D., V., J. (2016). Twenty First -century Education: Transformative Education for Sustainability and Responsible Citizenship. Journal of Teacher Education for Sustainability, 18 (1) 48-56.

Crockett, L., Jukes, I., \& Churches, A. (2011). Literacy is not enough. Thousand Oaks, CA: Corwin, a SAGE Company.

Cavanaugh, C. (2009). Getting students more learning time online: Distance education in support of expanded learning time in schools. Washington, DC: Center for American Progress.

Curtis, D. D., \& Lawson, M. J. (2001). Exploring collaborative online learning. Journal of Asynchronous learning networks, 5(1), 21-34.

Dillenbourg \& Schneider. (1995). Collaborative learning and the Internet. Retriveved from http://tecfasun1.unige.ch/tecfa/tecfa-research/CMC/colla/iccai951.html.ICCAI 95

Fox, S. B., \& McDermott, C., L. (2015). The Role of 21st -century Skills in Two Rural Regional Areas of Public Education. Journal for Leadership and Instruction. 26-30.

Garrison, D.R., \& Anderson, T. (2003). E-learning in 21st -century: A framework for research and practice. London: Routledge Falmer. 
Garrison, D.R. \& Arbaugh, J. (2007). Researching the Community of Inquiry Framework: review, issues, and future directions, Internet and Higher Education, 10(3), 157-172. http://dx.doi.org/10.1016/j.iheduc.2007.04.001.

Garrison, D. R., Anderson, T., \& Archer, W. (2001). Critical thinking, cognitive presence, and computer conferencing in distance education. The American Journal of Distance Education, 15(1), 7-23.

Garrison, D. R. (2003). Cognitive presence for effective asynchronous online learning: The role of reflective inquiry, self-direction and metacognition. Elements of quality online education: Practice and direction, 4(1), 47-58.

Garrison, D. R. (1997). Self-directed learning: Toward a comprehensive model. Adult Education Quarterly, 48(1), 15-31.

Guardado, M., \& Shi, L. (2007). ESL students' experiences of online peer feedback. Computers and Composition, 24(4), 443-461.

Jerald, C. D. (2009). Defining a 21st-century education. Center for Public education, 16.

Kaufman, (2013). K. 21 Ways to 21st -century skills: why students need them and ideas for practical implementation. Kappa Delta Pi Record, 49(2), 78-83. doi: 10.1080/00228958.2013.786594

Laurillard, D. (1993). Rethinking university teaching: a framework for the effective use of educational technology. London: Routledge.

Little, T. (2013). 21st -century Learning and Progressive Education: An Intersection. International Journal of Progressive Education, 9 (1) 84-96.

Moore, M. (1993). Three types of interaction. In K. Harry, M. John, \& D. Keegan (Eds.), Distance education: new perspectives. London: Routledge.

Norris, S.P., \& Ennis, R.H. (1989). Evaluating critical thinking. Pacific Grove, CA: Critical Thinking Press \& Software.

Pink, D. H. (2005). A whole new mind: Moving from the information age to the conceptual age. New York: Riverhead Books. (2005).

Pressley, M., \& McCormick, C. B. (1995). Advanced educational psychology for educators, researchers, and policymakers. New York: Harper Collins.

Ramsden, P. (1992). Learning to teach in higher education. London: Routledge.

Ravitz, J., Hixson, N., English, M., \& Mergendoller, J. (2012). Using project based learning to teach 21st-century skills: Findings from a statewide initiative. Paper presented at the Annual Meeting of the American Educational Research Association. Vancouver, BC. (2012, April 16). Retrieved from: http://www.bie.org/research/study/PBL_21CS_WV (Ravitz, Hixson, English \& Mergendoller, 2012)

Rodgers, C. (2002). Defining Reflection: another look at John Dewey and reflective thinking, Teachers College Record, 104(4), 842-866. http://dx.doi.org/10.1111/1467$\underline{9620.00181}$

Redmond, P. (2014). Reflection as an indicator of cognitive presence. E-Learning and Digital Media, 11(1), 46-58. 
Shear, L., Novais, G., Means, B., Gallagher, L., \& Langworthy, M. (2010). ITL research design. Menlo Park, CA: SRI International. (2010). Retrieved from http://ctl.sri.com/publications/downloads/ITL_Research_design_29Sept09.pdf

Slavin, R.E. (1987). Mastery Learning Reconsidered. Review of Educational Research. 57, 175-213.

Smith, F. (1990). Advocacy design center. New York: Teachers College, Columbia University.

Twigg, C. A. (2003). Models for online learning. Educause Review, 38, 28-38. 
10 | KLAUSA - Vol 2 No. 2 (2018) - DOI 